\title{
Maciej Kalwasiński
}

Uniwersytet Ekonomiczny we Wrocławiu

e-mail: maciej.kalwasinski@gmail.com

\section{AZJATYCKI BANK

\section{THE ASIAN INFRASTRUCTURE INVESTMENT BANK - ORIGIN AND OBJECTIVES}

DOI: $10.15611 / \mathrm{e} 21.2017 .1 .02$

JEL Classification: F02

Streszczenie: Rosnąca rola Chin i innych gospodarek wschodzących w globalnej gospodarce nie znajduje odzwierciedlenia $\mathrm{w}$ ich roli $\mathrm{w}$ globalnym władztwie ekonomicznym. Filarami światowego ładu finansowego pozostają zdominowane przez bogate kraje Zachodu - MFW i Grupa Banku Światowego. Wobec powolnych i niewystarczających reform najważniejszych międzynarodowych instytucji finansowych Chiny są inicjatorem tworzenia instytucji alternatywnych - w części komplementarnych, a w części konkurencyjnych wobec już istniejących. Jedną z nich jest Azjatycki Bank Inwestycji Infrastrukturalnych. Celem artykułu jest przedstawienie genezy powołania banku, w tym przede wszystkim powodów, które skłoniły Chiny do utworzenia nowego regionalnego banku rozwoju, a inne kraje - do przystąpienia do chińskiej inicjatywy oraz struktury i celów działalności instytucji. Przeprowadzona w artykule analiza wskazuje na istotną zmianę w strukturze systemu międzynarodowego, odchodzącego od systemu jednobiegunowego, i rosnące wpływy Chin na arenie międzynarodowej.

Słowa kluczowe: Chiny, Azjatycki Bank Inwestycji Infrastrukturalnych, AIIB, Międzynarodowy Fundusz Walutowy, Bank Światowy.

Summary: The increasing role of China and developing countries in the global economy is not reflected in their role in the global economic governance. IMF and the World Bank Group, which are dominated by the Western countries, remain the pillars of the global economic order. Confronted with sluggish and insufficient reform of the crucial multilateral financial institutions, China initiates the creation of the alternative institutions - in part complementary, in part competitive with the existing ones. Asian Infrastructure Investment Bank is one such initiative. The purpose of this article is to present AIIB's roots in particular the reasons which led China to create a new regional development bank and other countries' motives to join the inititative as well as to discribe the AIIB's structure and objectives. The analysis carried out in the article indicates a significant change in the structure of the international system, departing from the unipolar system, and the growing influence of China in the international arena.

Keywords: China, Asian Infrastructure Investment Bank, AIIB, International Monetary Fund, World Bank. 


\section{Wstęp}

Dotychczasowy światowy ład finansowy, opierający się na zdominowanych przez kraje Zachodu instytucjach utworzonych przed ponad siedemdziesięcioma laty podczas konferencji w Bretton Woods, jest w ostatnich latach coraz silniej kontestowany przez kraje rozwijające się. Dekady dynamicznego wzrostu pozwoliły dołączyć kilku z nich do grona największych gospodarek globu. Na pierwszy plan wysunął się spektakularny przypadek Chin, które w kategoriach PKB nominalnego są obecnie drugą największą gospodarką świata, a uwzględniając parytet siły nabywczej - pierwszą. Państwo Środka jest również największym eksporterem i drugim importerem na świecie, głównym odbiorcą BIZ i drugim inwestorem, podstawowym wierzycielem zagranicznym USA i posiadaczem rekordowych aktywów rezerwowych.

Rosnąca rola Chin w gospodarce światowej nie znajduje odzwierciedlenia w roli w najważniejszych międzynarodowych instytucjach finansowych - Międzynarodowym Funduszu Walutowym (MFW) i Banku Światowym (BŚ). Tymczasem piąta generacja chińskich przywódców modyfikuje podstawowe założenia polityki zagranicznej Państwa Środka ustanowione jeszcze w poprzednim wieku. Hasła „,skrywania światła i kultywowania ciemności” czy „pokojowego wzrastania” są zastępowane przez „renesans chińskiego narodu” i „dyplomację mocarstwową”. Powstają ambitne projekty międzynarodowe, jak koncepcja pn. „Pas i Droga” czy alternatywne instytucje międzynarodowe - Nowy Bank Rozwoju BRICS oraz Azjatycki Bank Inwestycji Infrastrukturalnych (Asian Infrastructure Investment Bank - AIIB). Aktywna polityka zagraniczna Pekinu staje się przyczynkiem do dyskusji o przyszłym kształcie systemu międzynarodowego i roli dotychczasowego hegemona - Stanów Zjednoczonych. System jednobiegunowy, który wykształcił się po upadku ZSRR, przekształca się, zgodnie z teorią równowagi sił, w stronę systemu wielobiegunowego [Czaputowicz 2007, s. 187]. Główną areną rywalizacji jest region Azji i Pacyfiku, gdzie ścierają się interesy USA i potęg regionalnych - Chin, Japonii, Rosji, Indii, Iranu i Arabii Saudyjskiej.

Celem artykułu jest przedstawienie powodów, które skłoniły Chiny do utworzenia nowego regionalnego banku rozwoju, a inne kraje - do przystąpienia do chińskiej inicjatywy. W tekście zarysowano historię powstania i ewolucji międzynarodowych instytucji finansowych - MFW i Banku Światowego, a także ich krytykę w kontekście rosnącego udziału krajów rozwijających się w gospodarce światowej. Opisano w nim również genezę powstania, strukturę i organy oraz cele Azjatyckiego Banku Inwestycji Infrastrukturalnych, a także zaprezentowano motywy, którymi kierowały się Chiny, decydując się na powołanie banku, oraz inne kraje, wstępując do AIIB. 


\section{Krytyka instytucji Bretton Woods}

Międzynarodowy Fundusz Walutowy i Bank Światowy ${ }^{1}$ zostały powołane na mocy ustaleń zawartych podczas Monetarnej i Finansowej Konferencji Narodów Zjednoczonych w Bretton Woods w 1944 roku. Zgodnie z wynegocjowanymi przez 44 kraje ramami funkcjonowania międzynarodowej współpracy gospodarczej MFW miał być odpowiedzialny za stworzenie powojennego ładu finansowego i stanie na jego straży, natomiast BŚ miał udzielać pomocy finansowej krajom zniszczonym przez II wojnę światową. Podczas spotkania w Bretton Woods zaproponowano również powołanie Międzynarodowej Organizacji Handlu, ale ostatecznie strony nie porozumiały się w tej sprawie. Jednak w 1948 roku wszedł w życie Układ Ogólny GATT, który od 1995 roku został przekształcony w Światową Organizację Handlu. $\mathrm{Na}$ przełomie lat 50. i 60. powstały regionalne banki rozwojowe - Międzyamerykański (1959), Afrykański (1964) i Azjatycki (1966). W 1964 roku utworzono UNCTAD - organ pomocniczy ONZ. W 1991 roku działalność rozpoczął Europejski Bank Odbudowy i Rozwoju. W 2009 roku powstała Rada Stabilności Finansowej.

We wszystkich instytucjach kluczową rolę odgrywają kraje Zachodu, a szczególnie USA, mające największe udziały m.in. w MFW i BŚ. Fotel prezesa MFW tradycyjnie przypada Europejczykowi, Banku Światowego - Amerykaninowi, a Azjatyckiego Banku Rozwoju - Japończykowi. Początkowa dominująca pozycja Waszyngtonu była w pełni uzasadniona - szacuje się, że tuż po II wojnie światowej USA generowały około połowy globalnego PKB [Lundestad 2012, s. 12]. Do największych gospodarek świata należały również w okresie powojennym kraje europejskie i Kanada, a w kolejnych dekadach - Japonia. Jednak na skutek dynamicznego wzrostu gospodarczego państw rozwijających się, szczególnie w ostatnich 15 latach, układ sił w globalnej gospodarce ulega zmianie (rys. 1).

Tymczasem udział krajów BRICS w głosach w Międzynarodowym Banku Odbudowy i Rozwoju wynosi zaledwie $13,1 \%$, podczas gdy ich udział w światowym PKB nominalnym to $23,1 \%$. Chiny kontrolują, co prawda, trzecią co do wielkości liczbę głosów (stanowiących 4,78\% łącznej liczby głosów), ale to wciąż ponad trzykrotnie mniej niż Stany Zjednoczone (15,98\%) i mniej niż Japonia (7,40\%), której gospodarka jest trzykrotnie mniejsza od chińskiej. Dysproporcje widać również w przypadku Azjatyckiego Banku Rozwoju (ABR), w którym udziały USA i Japonii wynoszą po $12,8 \%$, a Chin - 5,5\%. W MFW udział głosów Państwa Środka był do stycznia 2016 roku ponad czterokrotnie mniejszy niż USA. Po pięciu latach od piętnastego przeglądu kwot udziałowych Kongres USA zaakceptował reformę zakładającą podwojenie kapitału własnego Funduszu (z 238,5 do 477 mld SDR, czyli ok. 659 mld USD) oraz wzrost udziałów krajów rozwijających się (wśród 10 najwięk-

${ }^{1}$ Używane w artykule określenie „Bank Światowy” odnosi się do Grupy Banku Światowego, do której należą Międzynarodowy Bank Odbudowy i Rozwoju (IBRD), Międzynarodowe Stowarzyszenie Rozwoju (IDA) i Międzynarodowa Korporacja Finansowa (IFC). 


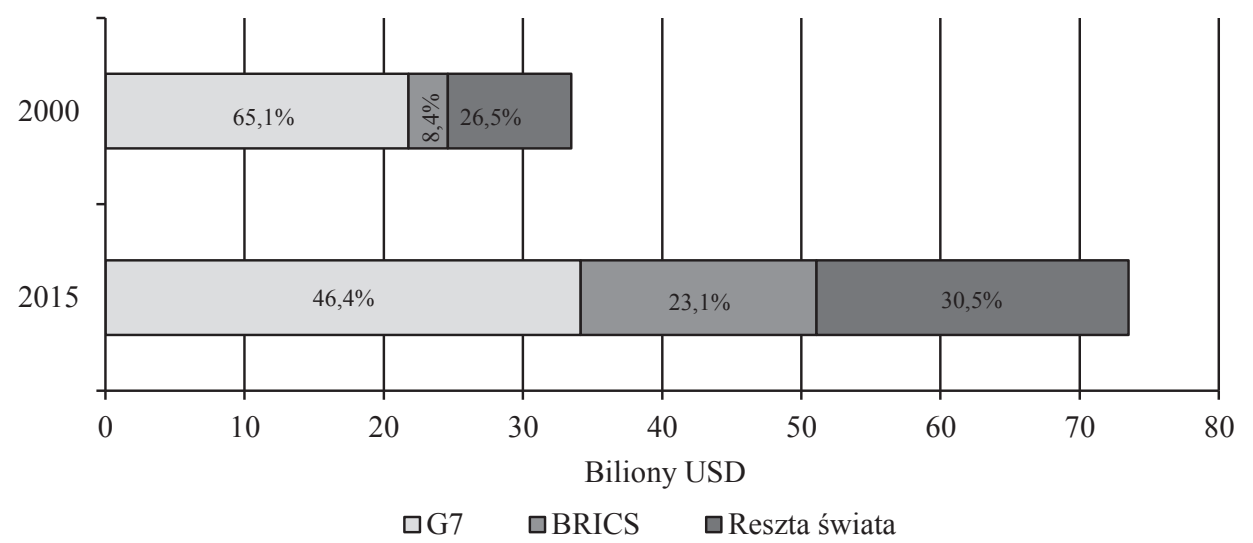

Rys. 1. Udział krajów G7, BRICS i reszty świata w światowym PKB nominalnym w latach 2000-2015 Źródło: opracowanie własne na podstawie [MFW 2015].

szych udziałowców MFW znalazły się cztery z nich: Chiny, Indie Rosja i Brazylia), co umożliwiło wprowadzenie zmian w życie. Jednak nawet po reformie udział głosów Chin pozostaje ponad dwukrotnie mniejszy niż USA i minimalnie mniejszy od Japonii. Cztery największe kraje Unii Europejskiej, stanowiące niecałe 15\% światowej gospodarki, kontrolują ponad 16\% głosów, a kraje BRICS, których udział w PKB świata wynosi ok. 23\%, niewiele ponad 14\% głosów. Stany Zjednoczone wciąż mogą blokować najważniejsze decyzje Funduszu, ponieważ mają ponad 15-procentowy udział w kwocie całkowitej oraz głosach, podczas gdy do podejmowania kluczowych decyzji potrzebna jest większość $85 \%{ }^{2}$.

Wielkość kwoty udziałowej danego kraju determinuje nie tylko liczbę przysługujących mu głosów w MFW, ale również: przydział SDR-ów zwiększających aktywa rezerwowe państwa oraz możliwości pożyczkowe - określane w programach dostosowawczych jako procent kwoty udziałowej państwa, przez co kraje bogatsze mają dostęp do większych środków [Adamczyk 2011, s. 14].

Najważniejsze międzynarodowe instytucje finansowe są krytykowane nie tylko za to, że ich struktura nie nadąża za zmianami w światowej gospodarce, ale również za narzucanie pożyczkobiorcom nieprzystających do ich możliwości i potrzeb rozwiązań w polityce gospodarczej, zgodnie z wolą dominujących krajów Zachodu. Za sprawą narastającego zadłużenia zagranicznego, wzrostu cen paliw po kryzysie naftowym, nieudanych prób zwiększenia roli państwowego interwencjonizmu w państwach rozwijających się, sukcesów liberalnej polityki gospodarczej rządów Ronalda Reagana w USA i Margaret Thatcher w Wielkiej Brytanii oraz początku upadku

${ }^{2}$ Szerszą, kompleksową krytykę reformy MFW przedstawiono w artykule: Still in the Woods: Gridlock in the IMF and the World Bank puts multilateralism at risk [Vestergaard, Wade 2014]. 
Tabela 1. Udział wybranych krajów w globalnym PKB oraz głosach w MBOiR, ABR i MFW

\begin{tabular}{|l|l|c|r|r|r|r|}
\hline \multicolumn{1}{|c|}{ Kraj } & Grupa & $\begin{array}{c}\text { Udział } \\
\text { w globalnym } \\
\text { PKB* }\end{array}$ & MBOiR & ABR & MFW & $\begin{array}{c}\text { MFW } \\
\text { po reformie** }\end{array}$ \\
\hline USA & G7 & 24,4 & 16,0 & 12,8 & 16,7 & 16,5 \\
\hline Japonia & G7 & 5,6 & 7,4 & 12,8 & 6,2 & 6,1 \\
\hline Niemcy & G7 & 4,6 & 4,3 & 3,8 & 5,8 & 5,3 \\
\hline Wielka Brytania & G7 & 3,9 & 4,1 & 1,9 & 4,3 & 4 \\
\hline Francja & G7 & 3,3 & 4,1 & 2,2 & 4,3 & 4 \\
\hline Włochy & G7 & 2,5 & 2,6 & 1,8 & 3,2 & 3 \\
\hline Kanada & G7 & 2,1 & 2,6 & 4,5 & 2,6 & 2,2 \\
\hline Chiny & BRICS & 15,5 & 4,8 & 5,5 & 3,8 & 6,1 \\
\hline Brazylia & BRICS & 2,4 & 1,9 & - & 1,7 & 2,2 \\
\hline Indie & BRICS & 3 & 3,0 & 5,4 & 2,3 & 2,6 \\
\hline Rosja & BRICS & 1,7 & 2,8 & - & 2,4 & 2,6 \\
\hline RPA & BRICS & 0,4 & 0,8 & - & 0,8 & 0,6 \\
\hline
\end{tabular}

* PKB nominalne,

** czternasty przegląd kwot udziałowych.

Źródło: opracowanie własne na podstawie danych MFW, BŚ, ABR.

ZSRR, MFW i BŚ wróciły na przełomie lat 80 . i 90. do strategii prorynkowych. Ich podstawą jest konsensus waszyngtoński - koncepcja zaprezentowana w 1989 roku przez Johna Williamsona, zakładająca prymat wolnego rynku nad protekcjonizmem $\mathrm{i}$ interwencjonizmem. Miała ona zagwarantować krajom rozwijającym się ustabilizowanie sytuacji gospodarczej (ograniczanie zbyt wysokiej inflacji i osiąganie równowagi bilansu płatniczego), przywrócenie wypłacalności i wiarygodności kredytowej oraz wejście na ścieżkę wzrostu gospodarczego. Kraje ubiegające się o pomoc instytucji międzynarodowych musiały realizować programy dostosowań strukturalnych oparte na KW i zakładające m.in. zachowanie dyscypliny fiskalnej, liberalizację stóp procentowych, handlu zagranicznego i przepływów kapitałowych, prywatyzację państwowych przedsiębiorstw oraz deregulację [Fiedor, Kociszewski (red.) 2010, s. 228-230].

Reformy przeprowadzane zgodnie z ideą konsensusu często przynosiły negatywne efekty. Kociszewski wskazuje przykłady krajów Ameryki Południowej Meksyku, Argentyny i Brazylii, Azji - Indonezji, Afryki Subsaharyjskiej - Malawi, Zambii i Kongo, oraz częściowy sukces krajów byłego bloku wschodniego, w tym Polski. Błędy polityki MFW widać szczególnie wyraźnie w krajach najbiedniejszych - w Malawi przyczyniły się do klęski głodu, w Zambii doprowadziły do poważnych problemów w sektorze górniczym i rolniczym, a w Zairze (aktualnie Kongo) - do pogorszenia sytuacji na rynku pracy i ograniczenia produkcji miedzi. Krytycy zarzucają Funduszowi brak elastyczności - programy MFW nie były dostosowane do 
potrzeb i możliwości konkretnych państw. Wiele z nich nie było gotowych na implementację polityki neoliberalnej z powodów politycznych, kulturowych, religijnych czy geograficznych. Słabość instytucji sprzyjała korupcji, a niedojrzałość systemów finansowych i brak odpowiednich regulacji ograniczały możliwość absorpcji środków z zagranicy. Szybkie wprowadzanie reform wywoływało negatywne skutki społeczne - zubożenie części społeczeństwa, wzrost bezrobocia czy nierówności społecznych. Skomplikowane procedury opóźniały przyznawanie środków i znacznie zwiększały koszty transakcyjne. Ponadto fundusze trafiały wielokrotnie do tych samych, niewypłacalnych pożyczkobiorców czy krajów ważnych geopolitycznie, a nie najbardziej potrzebujących. Z kolei inne kraje nie były w stanie uzyskać pomocy, ponieważ nie spełniały restrykcyjnych wymagań, podczas gdy np. Rosja korzystała ze wsparcia, mimo nierealizowania zaleceń Funduszu [Fiedor, Kociszewski (red.) 2010, s. 234-235, 238].

W poprzedniej dekadzie zmodyfikowano strategię działania MFW - zwrócono uwagę przede wszystkim na reformę nadzoru nad krajami członkowskimi (m.in. rynkami finansowymi), wprowadzono nowe instrumenty wsparcia dla państw doświadczających przejściowych problemów (elastyczna linia kredytowa) oraz podkreślono znaczenie działania prewencyjnego (analizy ryzyka makroekonomicznego, formułowanie planów regionalnych) [Fiedor, Kociszewski (red.) 2010, s. 240; Adamczyk 2011, s. 18]. Nie zapobiegło to jednak wybuchowi światowego kryzysu finansowego zapoczątkowanego w 2008 roku przez upadek banku Lehman Brothers. Pogłębiające się procesy globalizacji, liberalizacji i deregulacji umożliwiły błyskawiczny transfer kapitału, co doprowadziło do rozlania się zjawisk kryzysowych na niemal cały świat. Szczególnie dotknięte zostały wysoko rozwinięte kraje południa Europy, gdzie poziom zadłużenia był bardzo wysoki - w roku 2007 wskaźnik zadłużenia sektora publicznego, korporacyjnego i gospodarstw domowych do PKB wynosił w Portugalii i Hiszpanii ponad $150 \%$, a w Grecji ponad $100 \%$ - a wraz ze spadkiem PKB i napływem środków z Funduszu w kolejnym latach wzrósł do odpowiednio: 358\%, 313\% i 317\% w 2014 roku [Dobbs i in. 2015, s. 4], co przy równoczesnym wzroście rentowności ich obligacji spowodowało, że kraje stanęły na granicy wypłacalności, bądź - jak w Grecji - przyczyniło się do niespłacenia części zapadających wobec MFW należności. Fakt, że środki trafiają obecnie do zamożniejszej części globu, dodatkowo potęguje niezadowolenie krajów rozwijających się z działania instytucji [Reinhart, Trebesch 2015, s. 3].

\section{Azjatycki Bank Inwestycji Infrastrukturalnych: geneza, struktura, cele}

Koncepcja utworzenia nowego azjatyckiego banku rozwoju po raz pierwszy została przedstawiona przez prezydenta Chin Xi Jinpinga w październiku 2013 roku podczas wizyty w Indonezji. Xi uzasadniał potrzebę powołania instytucji chęcią zwiększenia połączeń infrastrukturalnych Państwa Środka z krajami ASEAN. Przez kolej- 
ny rok inicjatywę poparło 21 krajów Azji, których przedstawiciele złożyli 24 października 2014 roku podpisy pod listem intencyjnym w sprawie powołania Azjatyckiego Banku Inwestycji Infrastrukturalnych. Równo miesiąc później chęć przystąpienia do banku wyraziło ostatnie państwo należące do ASEAN-u: Indonezja.

W styczniu 2015 roku do grona potencjalnych członków założycieli dołączył pierwszy kraj należący do OECD - Nowa Zelandia. 12 marca Chiny otrzymały aplikację od Wielkiej Brytanii - państwa należącego do grupy G7, Unii Europejskiej i jednego z najbliższych sojuszników Stanów Zjednoczonych. W kolejnych dniach formalne deklaracje złożyły Niemcy, Francja i Włochy.

Decyzja największych krajów Unii Europejskiej została negatywnie odebrana przez USA i zdziwiła władze w Pekinie. Oficjalnie przedstawiciele władz Stanów Zjednoczonych wyrażali wątpliwości dotyczące funkcjonowania nowej instytucji zachowania standardów wyznaczanych przez Bank Światowy: transparentności procedur zamówień publicznych czy uwzględniania praw człowieka i dbałości o stan środowiska naturalnego przy realizacji projektów przez AIIB. Przede wszystkim obawiano się jednak, że bank będzie narzędziem do realizacji chińskich interesów w regionie - wywierania nacisków na azjatyckich partnerów i rozszerzania sfery wpływów Pekinu, co mogłoby stanowić zagrożenie dla pozycji USA w Azji [Perlez]. Jako przykład wskazywano chińską pomoc bilateralną dla krajów rozwijających się?.

Stanowcza krytyka międzynarodowej opinii publicznej skłoniła Stany Zjednoczone do zmiany stanowiska. Eksperci wytykali administracji amerykańskiej, że sama zachęcała Chińczyków do większego udziału w globalnym władztwie ekonomicznym, nazywając Pekin ,jeźdźcem na gapę" międzynarodowych stosunków gospodarczych. Gdy Chiny mocniej zaangażowały się w kwestie międzynarodowe, Stany Zjednoczone zaczęły wyrażać zaniepokojenie rosnącą rolą Państwa Środka. Prezydent Obama w dorocznym przemówieniu State of the Union w styczniu 2015 roku mówił: „Chiny chcą tworzyć zasady obowiązujące w najszybciej rozwijającym się regionie świata (...) Dlaczego mielibyśmy na to pozwolić? To my powinniśmy je tworzyć". To zdanie wskazuje zarówno na brak spójności w amerykańskich poglądach na rolę Chin w światowej gospodarce, jak i arogancję Waszyngtonu. Pod wpły-

\footnotetext{
${ }^{3}$ W latach 2007-2014 Państwo Środka udzieliło krajom Ameryki Południowej pożyczek o wartości blisko 120 miliardów dolarów [China-Latin America Finance Database]. Pekin podkreśla, że przyznawanie środków nie wiąże się z wpływaniem na wewnętrzne sprawy pożyczkobiorców, tj. reformy gospodarcze czy polityczne, jak ma to miejsce w przypadku MFW czy BŚ. Fundusze przyznawane krajom rozwijającym się przez Chiny w ramach pomocy bilateralnej są jednak obwarowane innymi warunkami. W wielu przypadkach środki trafiają bezpośrednio do chińskich kontraktorów. Pekin uzasadnia taką politykę argumentami o korupcji panującej w wielu gospodarkach wschodzących i doświadczeniem chińskich firm nabytym podczas trzech dekad znaczących inwestycji infrastrukturalnych w Państwie Środka. Rywale wytykają Chińczykom, że udzielają pomocy niedemokratycznym i niestabilnym reżimom, finansowana przez Pekin infrastruktura jest niepotrzebna, a jej budowa często związana jest np. z przymusowymi przesiedleniami lokalnej ludności [Forsythe, Sanderson 2013].
} 
wem nacisków opinii publicznej przedstawiciele rządu USA ostatecznie poparli utworzenie AIIB [Xu].

Do 31 marca 2015 roku 57 krajów formalnie zadeklarowało chęć przystąpienia do AIIB i zostało zaakceptowanych przez Chińczyków jako potencjalni członkowie założyciele (Prospective Founding Members) banku. Akcesu do banku nie zgłosili m.in. Amerykanie, Japończycy i Kanadyjczycy. 29 czerwca przedstawiciele 50 krajów złożyli podpisy pod statutem instytucji (Articles of Agreement), a pozostałych siedem państw uczyniło to do końca ubiegłego roku. Bank został formalnie powołany 25 grudnia, gdy dokumenty ratyfikacyjne złożyło 17 krajów o łącznych udziałach przekraczających 50\%. Ceremonia inauguracyjna Azjatyckiego Banku Inwestycji Infrastrukturalnych odbyła się 16 stycznia 2016 roku w Pekinie. W pierwszych obradach Rady Gubernatorów uczestniczyli przedstawiciele 30 krajów, które ratyfikowały umowę założycielską banku ${ }^{4}$, oraz reprezentanci pozostałych 27 potencjalnych członków założycieli. Pozostali potencjalni członkowie założyciele mają czas na ratyfikację do końca bieżącego roku. Rada Gubernatorów może jednak wydłużyć ten termin.

Tabela 2. Najważniejsze wydarzenia w historii AIIB

\begin{tabular}{|c|l|}
\hline \multicolumn{1}{|c|}{ Data } & \multicolumn{1}{|c|}{ Wydarzenie } \\
\hline 2 X 2013 r. & $\begin{array}{l}\text { Prezydent Xi Jinping przedstawia propozycję utworzenia azjatyckiego banku } \\
\text { inwestycyjnego podczas wizyty w Indonezji. }\end{array}$ \\
\hline 24 X 2014 r. & $\begin{array}{l}\text { Przedstawiciele 21 krajów azjatyckich składają podpis pod listem intencyjnym } \\
\text { w sprawie powołania AIIB. }\end{array}$ \\
\hline 24 XI 2014 r. & Indonezja, ostatni kraj ASEAN, zgłasza akces do banku. \\
\hline 12 III 2015 r. & $\begin{array}{l}\text { Oficjalną intencję przystąpienia do grona członków założycieli banku składa Wielka } \\
\text { Brytania. }\end{array}$ \\
\hline 17 III 2015 r. & Analogiczne deklaracje składają Niemcy, Francja i Włochy. \\
\hline 31 III 2015 r. & $\begin{array}{l}\text { Ostatni dzień składania deklaracji przystąpienia do grona członków założycieli. } \\
\text { Chiny ogłaszają, że chęć wyraziło 57 krajów, w tym m.in. Polska. }\end{array}$ \\
\hline 29 VI 2015 r. & Przedstawiciele 50 krajów składają podpis pod statutem AIIB \\
\hline 25 XII 2015 r. & $\begin{array}{l}\text { AIIB zostaje formalnie powołany - 17 członków, których łączny udział w banku } \\
\text { wynosi 50,1\%, ratyfikowało statut. }\end{array}$ \\
\hline 31 XII 2015 r. & Przedstawiciel ostatniego z 57 krajów założycieli składa podpis pod statutem AIIB. \\
\hline $16-18$ I 2016 r. & $\begin{array}{l}\text { Ceremonia inauguracyjna oraz pierwsze spotkanie Rady Gubernatorów i Rady } \\
\text { Dyrektorów Banku. }\end{array}$ \\
\hline
\end{tabular}

Źródło: opracowanie własne na podstawie informacji ze strony internetowej [www.aiib.org].

${ }^{4}$ Austria, Holandia, Luksemburg, Niemcy, Norwegia, Wielka Brytania, Australia, Brunei, Gruzja, Jordania, Korea Południowa, Myanmar, Mongolia, Nowa Zelandia, Pakistan, Singapur, Rosja, Malediwy, Dania, Finlandia, Indie, Indonezja, Izrael, Malta, Nepal, Laos, Tadżykistan, Turcja, Zjednoczone Emiraty Arabskie oraz Chiny. 


\subsection{Struktura i organy AIIB}

75\% udziałów w Banku objęli członkowie regionalni - państwa Azji i Pacyfiku, a 25\% - członkowie spoza regionu. Największymi udziałowcami są Chiny $(30,34 \%)$, Indie (8,52\%), Rosja (6,66\%), Niemcy $(4,57 \%)$ i Korea Południowa (3,81\%). Ich udział w głosach wynosi odpowiednio: $26,06 \%, 7,51 \%, 5,93 \%, 4,15 \%$ i 3,50\%. Kraje BRICS mają 49,36\% łącznych udziałów oraz 43,29\% głosów. Jako że do podjęcia najważniejszych decyzji (np. zwiększenia kapitału Banku, udziałów kraju członkowskiego czy wybór prezydenta) potrzebna jest większość 3/4 głosów, Chiny mają prawo weta. Wiceminister finansów Chin stwierdził, że taki podział głosów jest „naturalnym wynikiem" obowiązujących zasad, ale zmieni się wraz z dołączeniem do banku kolejnych członków [China Daily 2016]. Liczba głosów przypadająca na kraj jest sumą głosów podstawowych, przysługujących krajom założycielskim i zależnych od kwoty udziałowej. Głosy podstawowe stanowiące $12 \%$ łącznej liczby głosów są dzielone równo między wszystkie kraje członkowskie - obecnie przypada 2430 głosów na państwo. Każdy kraj założycielski otrzymał dodatkowo 600 głosów.

W statucie banku zostały wyszczególnione jego organy oraz ich prawa i obowiązki. Do władz należą: Rada Gubernatorów, Rada Dyrektorów i prezydent.

Najwyższym organem decyzyjnym jest Rada Gubernatorów, w której skład wchodzą zwykle ministrowie finansów lub prezesi narodowych banków centralnych wszystkich krajów członkowskich. Rada będzie się zbierać raz w roku. Do wyłącznych kompetencji Rady należą: decyzja o przyjęciu nowego członka banku, zwiększenie lub zmniejszenie kapitału banku, zawieszenie kraju członkowskiego czy wybór prezydenta oraz dyrektorów banku. Pierwszym przewodniczącym Rady Gubernatorów został minister finansów Chin Lou Jiwei, a jego zastępcami zostali minister finansów Indonezji Bambang Brodjonegoro i sekretarz stanu w Ministerstwie Finansów Niemiec Thomas Steffen.

W skład Rady Dyrektorów wchodzi dwanaście osób - dziewięć wybranych przez członków regionalnych, a trzech przez członków spoza regionu. Państwa spoza regionu podzieliły się na trzy konstytuanty (każdej przysługuje stanowisko dyrektora) skupiające: państwa strefy euro; pozostałe państwa UE i inne państwa europejskie (Wielka Brytania, Polska, Dania, Islandia, Norwegia, Szwajcaria) oraz państwa pozaeuropejskie (Brazylia, Egipt i RPA). W skład pierwszej Rady weszli obywatele ZEA, Nepalu, Indonezji, Australii, Rosji, Indii, Korei Południowej, Turcji, Chin, Niemiec, Wielkiej Brytanii i Brazylii. Dyrektor jest wybierany na dwuletnią kadencję z możliwością reelekcji. W przeciwieństwie do Rady Dyrektorów Grupy Banku Światowego, analogiczny organ AIIB nie będzie na stałe funkcjonował w siedzibie Banku, chyba że inaczej zarządzi Rada Gubernatorów. Rada Dyrektorów ma się zbierać przynajmniej raz w kwartale. Do głównych zadań Rady Dyrektorów należą: przygotowanie prac Rady Gubernatorów, stanowienie polityki Banku, w tym podejmowanie decyzji w najważniejszych kwestiach finansowych i operacyjnych oraz 
Tabela 3. Udziały i głosy regionalnych i pozaregionalnych członków założycieli AIIB

\begin{tabular}{|c|c|c|c|c|c|c|c|}
\hline Lp. & Kraje regionalne & $\begin{array}{l}\text { Udziały } \\
\text { (w \%) }\end{array}$ & $\begin{array}{l}\text { Głosy } \\
(\mathrm{w} \%)\end{array}$ & Lp. & $\begin{array}{c}\text { Kraje } \\
\text { pozaregionalne }\end{array}$ & $\begin{array}{l}\text { Udziały } \\
\text { (w \%) }\end{array}$ & $\begin{array}{l}\text { Głosy } \\
(\mathrm{w} \%)\end{array}$ \\
\hline 1 & Chiny & 30,34 & 26,06 & 1 & Niemcy & 4,57 & 4,15 \\
\hline 2 & Indie & 8,52 & 7,51 & 2 & Francja & 3,44 & 3,19 \\
\hline 3 & Rosja & 6,66 & 5,93 & 3 & Brazylia & 3,24 & 3,02 \\
\hline 4 & Korea Płd. & 3,81 & 3,50 & 4 & Wielka Brytania & 3,11 & 2,91 \\
\hline 5 & Australia & 3,76 & 3,46 & 5 & Włochy & 2,62 & 2,49 \\
\hline 6 & Indonezja & 3,42 & 3,17 & 6 & Hiszpania & 1,79 & 1,79 \\
\hline 7 & Turcja & 2,66 & 2,52 & 7 & Holandia & 1,05 & 1,16 \\
\hline 8 & Arabia Saudyjska & 2,59 & 2,47 & 8 & Polska & 0,85 & 0,98 \\
\hline 9 & Iran & 1,61 & 1,63 & 9 & Szwajcaria & 0,72 & 0,87 \\
\hline 10 & Tajlandia & 1,45 & 1,50 & 10 & Egipt & 0,66 & 0,83 \\
\hline 11 & ZEA & 1,21 & 1,29 & 11 & Szwecja & 0,64 & 0,81 \\
\hline 12 & Pakistan & 1,05 & 1,16 & 12 & RPA & 0,60 & 0,77 \\
\hline 13 & Filipiny & 1,00 & 1,11 & 13 & Norwegia & 0,56 & 0,74 \\
\hline 14 & Izrael & 0,76 & 0,91 & 14 & Austria & 0,51 & 0,70 \\
\hline 15 & Kazachstan & 0,74 & 0,89 & 15 & Dania & 0,38 & 0,58 \\
\hline 16 & Wietnam & 0,68 & 0,84 & 16 & Finlandia & 0,32 & 0,53 \\
\hline 17 & Bangladesz & 0,67 & 0,83 & 17 & Luksemburg & 0,07 & 0,32 \\
\hline 18 & Katar & 0,62 & 0,79 & 18 & Portugalia & 0,07 & 0,32 \\
\hline 19 & Kuwejt & 0,55 & 0,73 & 19 & Islandia & 0,02 & 0,28 \\
\hline 20 & Nowa Zelandia & 0,47 & 0,66 & 20 & Malta & 0,01 & 0,27 \\
\hline 21 & Sri Lanka & 0,27 & 0,50 & & & & \\
\hline 22 & Myanmar & 0,27 & 0,49 & & & & \\
\hline 23 & Oman & 0,26 & 0,49 & & & & \\
\hline 24 & Azerbejdżan & 0,26 & 0,48 & & & & \\
\hline 25 & Singapur & 0,25 & 0,48 & & & & \\
\hline 26 & Uzbekistan & 0,22 & 0,45 & & & & \\
\hline 27 & Jordania & 0,12 & 0,37 & & & & \\
\hline 28 & Malezja & 0,11 & 0,36 & & & & \\
\hline 29 & Nepal & 0,08 & 0,33 & & & & \\
\hline 30 & Kambodża & 0,06 & 0,32 & & & & \\
\hline 31 & Gruzja & 0,05 & 0,31 & & & & \\
\hline 32 & Brunei & 0,05 & 0,31 & & & & \\
\hline 33 & Laos & 0,04 & 0,30 & & & & \\
\hline 34 & Mongolia & 0,04 & 0,30 & & & & \\
\hline 35 & Tadżykistan & 0,03 & 0,29 & & & & \\
\hline 36 & Kirgistan & 0,03 & 0,29 & & & & \\
\hline 37 & Malediwy & 0,01 & 0,27 & & & & \\
\hline
\end{tabular}

Źródło: opracowanie własne na podstawie [AIIB 2015]. 
delegowanie uprawnień prezydentowi Banku, regularne nadzorowanie procesu zarządzania bankiem czy zatwierdzanie strategii, planu rocznego oraz budżetu banku.

Prezydent jest wybierany przez Radę Gubernatorów na pięcioletnią kadencję. Prezydent jest równocześnie przewodniczącym Rady Dyrektorów, ale nie ma prawa głosu, z wyjątkiem głosu decydującego w przypadku braku rozstrzygnięcia. Może również uczestniczyć w posiedzeniach Rady Gubernatorów. Jest przedstawicielem banku oraz szefem jego personelu. Prowadzi, pod kierunkiem Rady Dyrektorów, bieżącą politykę banku. Przygotowuje agendę spotkań Rad Gubernatorów i Dyrektorów. Pierwszym prezydentem został Chińczyk Jin Liqun. Stanowiska wiceprezydentów objęli obywatele Wielkiej Brytanii, Niemiec, Indii, Korei Południowej i Indonezji.

\subsection{Cele AIIB}

Azjatycki Bank Inwestycji Infrastrukturalnych jest nowym multilateralnym bankiem rozwojowym, którego głównym celem jest zapewnienie finansowego wsparcia dla budowy infrastruktury w Azji. AIIB ma stwarzać bodźce do wzrostu inwestycji na terenie Azji - w transporcie, energetyce czy telekomunikacji. Zapewniając część finansowania projektów infrastrukturalnych, bank poprawia klimat inwestycyjny w krajach regionu i zachęca do inwestycji w tych sektorach podmioty prywatne.

Zgodnie $\mathrm{z}$ art. 1 statutu celem banku jest:

- wspieranie zrównoważonego rozwoju ekonomicznego, tworzenie dobrobytu i poprawa łączności w Azji przez inwestycje w infrastrukturę oraz inne sektory produkcyjne oraz

- promowanie współpracy regionalnej i partnerstwa w rozwiązywaniu wyzwań rozwojowych przez bliską współpracę z innymi multilateralnymi oraz bilateralnymi instytucjami rozwojowymi.

Ten cel ma być osiągnięty przez realizację następujących zadań:

- wspieranie rozwojowych inwestycji publicznych i prywatnych w regionie, w szczególności tych rozwijających infrastrukturę oraz inne sektory produkcyjne,

- wykorzystywanie dostępnych zasobów do finansowania rozwoju regionu, w tym tych projektów i programów, które w najbardziej efektywny sposób przyczynią się do harmonijnego rozwoju gospodarczego regionu jako całości i ze specjalnym uwzględnieniem potrzeb mnie rozwiniętych państw regionu,

- pobudzanie prywatnych inwestycji w projekty, przedsiębiorstwa i działania przyczyniające się do rozwoju gospodarczego regionu, w szczególności w infrastrukturę oraz inne sektory produkcyjne, oraz uzupełnianie prywatnych inwestycji, gdy kapitał prywatny będzie niedostępny na rozsądnych warunkach,

- podejmowanie innych działań i zapewnianie innych usług, które mogą sprzyjać tym funkcjom.

Do podstawowych instrumentów finansowych, za pomocą których AIIB ma osiągać swoje cele, należą: kredyty bezpośrednie - udzielane samodzielnie lub 
współfinansowane, zakup udziałów w instytucjach i przedsiębiorstwach, gwarantowanie pożyczek na rozwój gospodarczy, zasoby Funduszy Specjalnych. Obok pomocy finansowej, bank ma również udzielać praktycznej pomocy technicznej.

Cele statutowe AIIB będą realizowane poprzez zasoby banku - własne oraz pożyczone. Fundusze AIIB mają pochodzić z kapitału założycielskiego gwarantowanego przez kraje członkowskie, emisji obligacji na rynkach finansowych oraz innych instrumentów finansowych. Całkowity kapitał założycielski banku wyniesie 100 miliardów dolarów, podzielonych na milion akcji po 100000 dolarów każda. $20 \%$ udziału to kapitał wpłacony, pozostałą część stanowi kapitał płatny na żądanie. Na zasoby własne (kapitał zakładowy) składają się wpłaty kwot członkowskich. Ich wysokość zależy od liczby udziałów danego członka, która wpływa z kolei na liczbę głosów w Radzie Gubernatorów. Pozyskanie dodatkowego kapitału ze źródeł prywatnych będzie zależeć od czynników zidentyfikowanych przez Chelsky’ego, Morela i Kabira: pozycji finansowej, wiarygodności kredytowej, polityki zarządzania ryzykiem, standardów corporate governance, perspektywy długoterminowej oraz wiedzy i doświadczenia kadry zarządzającej bankiem. Decyzja krajów Zachodu o przystąpieniu do AIIB powinna zatem zostać pozytywnie odebrana przez rynki finansowe. Państwa rozwinięte zapewnią większą wiarygodność nowej instytucji, a także mogą zagwarantować dostęp do nowoczesnych technologii, know-how i metod zarządzania. Obligacje emitowane przez AIIB mają szansę otrzymać najwyższą ocenę od agencji ratingowych. Przy założeniu, że AIIB uda się osiągnąć podobny poziom wskaźnika pożyczek do kapitału co ADB i IBRD, bank może zbudować portfolio pożyczkowe o wartości 200 mld USD [Reisen 2015, s. 3-5]. Obecnie szacuje się, że w 2016 r. bank udzieli od 0,5 do 1,2 mld USD pożyczek, a w kolejnych pięciu latach będzie to już 10-15 mld USD rocznie. Prezydent Jin Liqun zapowiedział, że bank udzieli pierwszych pożyczek do końca bieżącego roku [China Daily, 2016].

Mimo że AIIB nie udzielił jeszcze pierwszej pożyczki, już widać istotne skutki jego utworzenia: powstała nowa instytucja dająca krajom rozwijającym się większy udział w globalnym władztwie ekonomicznym, zgodnie z ich rosnącym udziałem w światowej gospodarce, pojawiło się kolejne forum współpracy krajów ekonomicznego Południa i Północy, Kongres USA zaakceptował po latach reformę MFW, a premier Japonii złożył obietnicę przekazania w najbliższych pięciu latach $110 \mathrm{mi}-$ liardów dolarów na projekty infrastrukturalne w Azji. Narastające bolączki gospodarek chińskiej (odpływ kapitału, wysoki poziom zadłużenia, wzrost kosztów pracy, stan środowiska naturalnego) i krajów rozwijających się (spadające ceny surowców, rosnące koszty obsługi zadłużenia związane $\mathrm{z}$ umacnianiem się dolara na skutek podwyżki stóp procentowych w USA) sprawiają, że nowa instytucja od początku będzie musiała funkcjonować w trudnym otoczeniu międzynarodowym i w krótkim okresie może nie być tak aktywna, jak się tego oczekuje. Jednak w długim okresie, w połączeniu z innymi, komplementarnymi chińskimi inicjatywami, może zmienić gospodarcze status quo w regionie i na świecie. 


\section{Motywy czlonkostwa w AIIB}

Obok wskazanych motywów utworzenia AIIB wynikających z niezadowolenia z roli krajów rozwijających się w najważniejszych międzynarodowych instytucji finansowych, poszczególni potencjalni członkowie założyciele kierowali się również innymi względami.

Rosnące znaczenie Chin w gospodarce światowej i wybuch globalnego kryzysu skłoniły władze w Pekinie do zrewidowania podstawowych założeń polityki zagranicznej. Pod rządami piątej generacji chińskich przywódców Państwo Środka odchodzi od dotychczasowej wizji polityki zagranicznej opierającej się na wykształconych jeszcze w czasach Denga Xiaopinga zasadach, na mocy których Chiny miały: uważnie obserwować i chłodno analizować sytuację, zabezpieczać swoje pozycje i interesy, nigdy nie starać się być przywódcą, nie stawać w pierwszym szeregu, zachowywać się powściągliwie, ale też ukrywać swe możliwości i zamierzenia [Góralczyk]. Odkąd Xi Jinping objął w 2013 roku urząd przewodniczącego Chińskiej Republiki Ludowej, wielokrotnie podkreślał konieczność reformy sytemu global governance, uwzględniającej wzrost znaczenia krajów rozwijających się [Xinhua 2015], wzywał do bardziej partnerskich relacji ze światowymi mocarstwami [Xinhua 2014] i odwoływał się do „wielkiego renesansu chińskiego narodu” [Yang].

W związku z tym Chiny podjęły wiele nowych, znaczących inicjatyw - powstała wizja reaktywacji historycznego Jedwabnego Szlaku pod nazwą „Pas i Droga” oraz utworzono specjalny Fundusz Jedwabnego Szlaku w wysokości 40 mld USD wspierający koncepcję. Pekin był również inicjatorem utworzenia Nowego Banku Rozwoju BRICS. Powołanie Azjatyckiego Banku Inwestycji Infrastrukturalnych jest kolejnym przykładem tworzenia przez Chińczyków instytucji alternatywnych wobec tych zdominowanych przez Zachód.

Równocześnie Chiny dążą do zwiększenia swojej roli w ramach rozwiązań już istniejących. Stąd postulaty reformy MFW i rosnące znaczenie forum G-20 kosztem G-7 oraz wzmocnienie współpracy w ramach grupy BRICS. Celem Państwa Środka nie jest zniszczenie lub opuszczenie najważniejszych międzynarodowych instytucji finansowych, co wielokrotnie podkreślali chińscy liderzy, ale zbudowanie uzupełniających - w części komplementarnych, a w części konkurencyjnych - kanałów kształtowania ładu międzynarodowego niebędących pod przywództwem Zachodu [Heilmann $\mathrm{i}$ in. 2014].

Dla Chin Azjatycki Bank Inwestycji Infrastrukturalnych jest przede wszystkim kluczowym elementem wizji Nowego Jedwabnego Szlaku, który ma połączyć siecią dróg, torów, mostów, lotnisk, portów itp. Państwo Środka przez Azję z Europą Zachodnią. Może to być szansa dla gorzej rozwiniętych chińskich regionów w centrum oraz na zachodzie i północy kraju. Dotychczasowy model rozwoju gospodarczego, oparty na ogromnych nakładach inwestycyjnych i wspieraniu eksportu, przynosi Chinom coraz mniejsze korzyści. Tempo wzrostu PKB wyraźnie zwalnia - w 2015 roku wyniosło $6,9 \%$, czyli najmniej od 25 lat, gdy na kraj nałożone zostały sankcje za 
masakrę na placu Tiananmen. Od 2003 roku udział inwestycji w PKB Chin przekracza $40 \%$, podczas gdy średnia globalna wynosi ok. 20\%. W 2001 roku wielkość eksportu dóbr i usług odpowiadała 20\% PKB, by sięgnąć 35,7\% w 2006 roku. Od tego momentu spada (z wyjątkiem roku 2009 ) i w 2014 roku wyniósł 22,6\% [Bank Światowy]. Od 2009 roku Chiny są największym eksporterem na świecie. Bezpośrednim skutkiem prowadzonej przez Pekin polityki gospodarczej jest pojawienie się nadwyżki zdolności produkcyjnych, szczególnie w sektorze zajmującym się produkcją stali, cementu czy aluminium. Wraz ze spadkiem nakładów na inwestycje spada zapotrzebowanie na materiały budowlane, co odbija się nie tylko na światowym rynku surowców, ale prowadzi również do obniżenia rentowności krajowych zakładów. AIIB może w pewnym, lecz ograniczonym, stopniu zagospodarować tę nadwyżkę.

Chiny mogą również podjąć próbę dywersyfikacji swoich aktywów rezerwowych i internacjonalizacji juana z pomocą nowej instytucji. Wskutek długoletniej polityki wspierania eksportu przez utrzymywanie zaniżonego kursu renminbi wobec dolara rezerwy walutowe denominowane w amerykańskiej walucie stanowią ok. $60 \%$ chińskich aktywów rezerwowych [Wang, Zheng 2012, s. 168]. Chiny będą mogły ulokować część z nich w bardziej rentowne niż niskooprocentowane obligacje USA papiery wartościowe emitowane przez AIIB. W najbliższej przyszłości bank ma udzielać kredytów denominowanych w dolarach [Waldau, Mitchell]. Stosowanie innych walut byłoby problematyczne, ponieważ składki członkowskie są regulowane $\mathrm{w}$ amerykańskiej walucie, a dolar jest powszechnie uznawanym środkiem płatniczym. Zastosowanie renminbi zmuszałoby kredytobiorcę do korzystania z chińskich dostawców materiałów czy usług budowlanych. Nie oznacza to jednak, że wraz ze wzrostem roli chińskiej waluty w globalnych płatnościach, przez środki pochodzące z AIIB, Pekin nie będzie podejmował próby internacjonalizacji juana. Wybuch globalnego kryzysu finansowego podkopał zaufanie do dolara i przekonał władze Chin do konieczności ograniczenia roli amerykańskiej waluty jako fundamentu światowego systemu finansowego.

Gwałtowny spadek cen ropy od lipca 2014 roku powoduje wzrost ryzyka niewypłacalności głównych kredytobiorców Chin - Wenezueli i Ekwadoru. Z poważnymi problemami gospodarczymi borykają się również inni odbiorcy chińskiego wsparcia - Argentyna i Zimbabwe. Przekazywanie im środków przez multilateralną instytucję pozwoli rozłożyć ryzyko niewypłacalności dłużników.

Brak rozwiniętej i dobrze funkcjonującej infrastruktury technicznej jest poważną barierą rozwoju dla krajów azjatyckich. 600 milionów ludzi w Azji wciąż nie ma dostępu do elektryczności, a 1,7 miliarda nie ma kanalizacji czy szamba. Z analiz Azjatyckiego Banku Rozwoju wynika, że środki potrzebne na inwestycje infrastrukturalne w regionie w latach 2010-2020 opiewają na kwotę ok. 8 bln USD [ADB 2010]. W 2014 roku ABR przeznaczył na ten cel 13,69 mld USD, a łącznie z projektami współfinansowanymi przez bank inwestycje wyniosły 23 mld USD. Z kolei działalność Banku Światowego nie skupia się na wspieraniu inwestycji infrastrukturalnych, lecz na szeroko pojętej walce z biedą. Dlatego chińska inicjatywa spotkała 
się z pozytywnym odzewem w regionie. Odpowiednia infrastruktura poprawia warunki prowadzenia działalności gospodarczej, zapewnia lepszy dostęp do dóbr i usług dla konsumentów, powoduje wzrost atrakcyjności inwestycyjnej obszaru, ułatwia prowadzenie handlu zagranicznego, wspiera mobilność siły roboczej. Może również uczynić wzrost gospodarczy bardziej inkluzywnym, np. przez łączenie z centrami biznesowymi niewielkich czy odległych skupisk ludności. Poziom infrastruktury jest jednym z kryteriów determinujących poziom rozwoju gospodarczego kraju [Fiedor, Kociszewski (red.) 2010, s. 21]. Dzięki AIIB kraje azjatyckie będą mogły korzystnie ulokować oszczędności obywateli i część aktywów rezerwowych w przedsięwzięciach wspierających rozwój gospodarczy.

Bogate kraje Zachodu liczyły przede wszystkim na pogłębienie relacji z drugą największą gospodarką globu. Mimo spowolnienia dynamiki wzrostu PKB, gospodarka Państwa Środka wciąż rozwija się w imponującym tempie - w 2014 roku zanotowano 7,3\% wzrostu, w 2015 roku - 6,9\%, a w latach 2016-2017 ma to być, według prognozy MFW, odpowiednio 6,3\% oraz 6\% [MFW 2015]. Chiny zamieszkuje ponad 1,3 miliarda ludzi, a dynamiczny rozwój w ciągu ostatnich trzech dekad spowodował powstanie liczącej kilkaset milionów ludzi klasy średniej, która z chęcią sięga po zagraniczne towary w poszukiwaniu wyższej jakości i prestiżu. Dlatego zachodnim przedsiębiorcom tak zależy na dobrych stosunkach zachodnich rządów z Pekinem. W ostatnich latach Chiny stały się również ogromnym eksporterem kapitału - w 2014 roku wartość chińskich bezpośrednich inwestycji zagranicznych sięgnęła 116 mld USD [UNCTAD 2015]. Kraje Europy Zachodniej wykazały się zatem ekonomicznym pragmatyzmem - w obliczu rosnącej roli Chin decyzja o poparciu inicjatywy Pekinu ma szanse przynieść wymierne korzyści polityczne i gospodarcze. Ponadto kraje strefy euro borykają się z poważnym spowolnieniem gospodarczym od 2008 roku tylko raz roczny wzrost PKB przekroczył 2\%, a w latach 2009, 2012 i 2013 PKB unii walutowej kurczyło się w porównaniu z rokiem poprzednim. Tymczasem wzrost gospodarczy w Azji utrzymuje się powyżej 5\% [MFW 2015]. Przyłączenie się do banku może ułatwić firmom spoza regionu dostęp do najbardziej dynamicznie rozwijającego się regionu świata - realizacja projektów finansowanych przez bank uwiarygodni przedsiębiorstwa wchodzące na rynek azjatycki.

Dla gospodarek opierających swój wzrost w znacznej mierze na eksporcie surowców uczestnictwo w chińskiej inicjatywie jest szansą na zwiększenie wartości eksportu w okresie niskich cen ropy, węgla czy gazu. Inwestycje w infrastrukturę wymagają nakładu m.in. surowców energetycznych czy metali. Z danych chińskiego General Administration of Customs wynika, że wskutek gwałtownej obniżki cen surowców rosyjski eksport do Chin zmniejszył się w ubiegłym roku o 20\% (w USD), brazylijski o $15 \%$, a australijski o $25 \%$.

Początkowe obawy Zachodu związane z dominującą rolą Chin w AIIB zostały częściowo rozwiane na skutek dołączenia do banku kilku krajów rozwiniętych. AIIB tym różni się od innych, nowych, regionalnych banków rozwojowych, że udziałowcami są nie tylko kraje ekonomicznego Południa, ale również przedstawiciele gospodarek rozwiniętych. 


\section{Zakończenie}

Azjatycki Bank Inwestycji Infrastrukturalnych jest odpowiedzią gospodarek wschodzących, na czele z Chinami, na niezadowolenie z funkcjonowania zdominowanych przez bogate kraje Zachodu międzynarodowych instytucji finansowych oraz dowodem ich rosnących ambicji dotyczących roli w kształtowaniu globalnego ładu. Chiny po latach niewielkiego zaangażowania w sprawy zagraniczne dążą do wzmocnienia swojej pozycji jako regionalnego mocarstwa oraz ważnego gracza globalnego w ramach ewolucji istniejącego porządku międzynarodowego. Ich celem nie jest jednak drastyczna i nagła zmiana obecnego porządku i sięgnięcie po status globalnego hegemona, lecz ewolucja, uwzględniająca zmiany zachodzące w światowej gospodarce - zanikającą dominację Stanów Zjednoczonych i wzrost znaczenia krajów rozwijających się, a także umacnianie układu multipolarnego.

Część krajów, jak USA czy Japonia, nie zdecydowała się na dołączenie do AIIB - inicjatywy kraju uważanego za rywala, bądź, jak Kanada czy Meksyk - nie chciały narażać się swojemu głównemu partnerowi - Stanom Zjednoczonym. Inne, kierując się ekonomicznym pragmatyzmem, poparły chińską inicjatywę. Chęć poprawienia stosunków z drugą największą gospodarką świata i wynikające z tego potencjalne korzyści przeważyły nad solidarnością transatlantycką. Doskonale obrazuje to wzrost znaczenia ekonomicznego i politycznego Państwa Środka oraz jest świadectwem sukcesu chińskiej dyplomacji. Znamionuje również istotną zmianę w strukturze systemu międzynarodowego, odchodzącego od systemu jednobiegunowego.

\section{Literatura}

Abe S., 2015, Speech at the Banquet of the 21st International Conference on the Future of Asia, japan. kantei.go.jp/97_abe/statement/201505/0521 foaspeech.html (1.02.2016).

Adamczyk M., 2011, Wplyw krytyki na zmiany zachodzace w Międzynarodowym Funduszu Walutowym, Ekonomia, nr 1 (13), s. 11-21.

ADB, 2010, Estimating Demand for Infrastructure in Energy, Transport, Telecommunications, Water and Sanitation in Asia and the Pacific: 2010-2020, ADBI Working Paper Series, no. 248.

ADB, 2015, ADB Annual Report 2014, www.adb.org/documents/adb-annual-report-2014 (1.02.2016). AIIB, 2015, Articles of Agreement of the Asian Infrastructure Investment Bank.

AIIB, 2016, By-Laws of the Asian Infrastructure Investment Bank.

Bank Światowy, International Bank for Reconstruction and Development Subscriptions and Voting Power of Member Countries (10.01.2016).

Baza danych Banku Światowego, http://data.worldbank.org/ (1.02.2016).

Baza danych MFW, www.imf.org/external/pubs/ft/weo/2015/02/weodata/index.aspx (10.01.2016).

Campanella M., 2014, The Internationalization of the Renminbi and the Rise of a Multipolar Currency System, ECIPE Working Paper, no. 01/2014.

China Daily, 2016, AIIB Chief Vows to Run Clean, Lean, Green Institution, http://europe.chinadaily. com.cn/business/2016-01/22/content_23206607.htm (1.02.2016).

China Focus: AIIB formally established in Beijing, http://news.xinhuanet.com/english/2015-12/25/c_ 134952386.htm (1.02.2016). 
China-Latin America Finance Database, www.thedialogue.org/map_list/ (1.02.2016).

Czaputowicz J., 2007, Teorie stosunków międzynarodowych. Krytyka i systematyzacja, Wydawnictwo Naukowe PWN, Warszawa.

Dobbs R., Lund S., Woetzel J., Mutafchieva M., 2015, Debt and (Not Much) Deleveraging, McKinsey\&Company.

Eurostat Database, http://ec.europa.eu/eurostat/data/database (1.02.2016).

Fiedor B., Kociszewski K. (red.), 2010, Ekonomia rozwoju, Wydawnictwo Uniwersytetu Ekonomicznego we Wrocławiu, Wrocław.

Forsythe M., Sanderson H., 2013, China's Superbank: Debt, Oil and Influence - How China Development Bank is Rewriting the Rules of Finance, Bloomberg Press, Singapore.

Góralczyk B., Nowa strategia Chin, które szykują się do skoku, www.obserwatorfinansowy.p1/tematy$\mathrm{ka} /$ makroekonomia/nowa-strategia-chin-ktore-szykuja-sie-do-skoku/ (1.02.2016).

Heilmann S., Rudolf M., Huotari M., Buckow J., 2014, China 's Shadow Foreign Policy: Parallel Structures Challenge the Established International Order, China Monitor 18, Mercator Institute for China Studies.

Lundestad G., 2012, The Rise and Decline of the American Empire: Power and its Limits in Comparative Perspective, Oxford University Press, Oxford.

MFW, 2011, Articles of Agreement of the International Monetary Fund.

MFW, 2015, Regional Economic Outlook Update: Asia and Pacific.

MFW, 2015, World Economic Outlook: Adjusting to Lower Commodity Prices.

Mohan R., Kapur M., 2015, Emerging Powers and Global Governance: Whither the IMF?, IMF Working Paper.

Obama B., 2015, Remarks by the President in State of the Union Address.

Perlez J., U.S. Opposing China's Answer to World Bank, The New York Times, 9.10.2014, http://www. nytimes.com/2014/10/10/world/asia/chinas-plan-for-regional-development-bank-runs-into-usopposition.html (1.02.2016).

Reinhart M., Trebesch C., 2015, The International Monetary Fund: 70 years of reinvention, NBER Working Paper, no. 21805.

Reisen H., 2015, Will the AIIB and the NDB help reform multilateral development banking?, Global Policy, 6(3), s. 297-304.

IMF Memebers' Quotas and Voting Power, and IMF Board of Governors, www.imf.org (1.01.2016)

IMF Quota and Governance Reform - Elements of an Agreement, www.imf.org (1.01.2016).

The General Administration of Customs, www.chinacustomsstat.com (1.02.2016)

UNCTAD, 2015, World Investment Report 2015.

Vestergaard J., Wade R., 2014, Still in the woods: Gridlock in the IMF and the World Bank puts multilateralism at risk, Global Policy, 6.1 (2015).

Waldau G., Mitchell T., China's New Asia Development Bank Will Lend in US Dollars, http://www. ft.com/intl/cms/s/0/762ce968-bcee-11e5-a8c6-deeeb63d6d4b.html (1.02.2016).

Wang G., Zheng Y., 2012, China: Development and Governance, World Scientific.

www.aiib.org (1.02.2016).

Xinhua, 2014, Xi Eyes More Enabling int'l Environment for China's Peaceful Development, http:// news.xinhuanet.com/english/china/2014-11/30/c_133822694.htm (1.02.2016).

Xinhua, 2015, Xi Stresses Urgency of Reforming Global Governance, http://news.xinhuanet.com/engli$\mathrm{sh} / 2015-10 / 13 / \mathrm{c}$ 134710464.htm (1.02.2016).

$\mathrm{Xu}$ W., United States Welcomes AIIB, http://www.chinadaily.com.cn/world/2015-05/16/content_ 20736902.htm (1.02.2016).

Yang F., Profile: Xi Jinping: Pursuing Dream for 1.3 Billion Chinese, http://news.xinhuanet.com/english/china/2013-03/17/c_124467411.htm (1.02.2016). 